\title{
Accounting Treatment of Research and Development Expenditure: A Critical Literature Review
}

\author{
Milton Owino, Omoro Nixon \\ School of Business, University of Nairobi, Nairobi, Kenya \\ Email address: \\ luckymilton@gmail.com (M. Owino),nixonoluoch2015@gmail.com (O. Nixon)
}

\section{To cite this article:}

Milton Owino, Omoro Nixon. Accounting Treatment of Research and Development Expenditure: A Critical Literature Review. International Journal of Accounting, Finance and Risk Management. Vol. 6, No. 2, 2021, pp. 36-45. doi: 10.11648/j.ijafrm.20210602.11

Received: February 20, 2021; Accepted: March 17, 2021; Published: April 7, 2021

\begin{abstract}
Intangible investments have been found to contribute largely to value enhancement in firms and economies that spend colossus resources on them. Despite being an important component of valuation, such investments are largely ignored or given subjective treatment by the existing accounting standards and consequently, not included on firm valuation. The American standard (FASB-S2) establishes standards of financial accounting and reporting for research and development (R\&D) costs. This Statement requires that $R \& D$ costs be charged to expense when incurred. It also requires a company to disclose in its financial statements the amount of R\&D that it charges to expense. On the other hand, the accounting for R\&D under IFRS standards requires judgment of the expectation of future economic benefit that will flow to the entity due to R\&D. If it can be "ascertained", then these costs should be treated as an asset rather than an expense since they meet the definition of an asset as prescribed by the IASB Framework for the Preparation and Presentation of Financial Statements. This paper, therefore, seeks to critically analyze the literary works of various researchers on the treatment and hence the impact of accounting for research and development expenditure on: firstly, the value relevance of financial information to investors; secondly, allocation of equity and debt resources to the firm; thirdly, growth of intangible assets; and lastly, firm value in capital markets. Previously studies conducted under here have cut across the accounting treatment of R\&D expenditure, and generally, internally generated intangibles using the International Financial Reporting Standards (IFRSs) and the U.S.' Generally Accepted Accounting Principles (GAAPs). Majority of the studies analyzed agree that sufficient disclosure of R\&D investment as well as other internally generated intangibles can supplement and improve the financial information provided by the firm. This in turn will improve the outlook of the financial statements which can improve their use and reliability to investors as well as give reliable inputs to financial analysts, thus improving the applied valuation models in computing dependable valuation figures for the firm. This, by and large, should avoid the negative consequences that may result from inadequate accounting treatment of R\&D expenditures.
\end{abstract}

Keywords: Research \& Development, Intangible Assets, Accounting Treatment

\section{Background}

Intangible assets (capital) such as R\&D have been found to play an important role in the performance of firms [45]. Firms involved in high R\&D expenditures are difficult to value because their future profits depend on the achievement of yet to be implemented and uncertain experimental models. However, there is insufficient reporting of $R \& D$ expenditure resulting in inadequate information for valuation purposes [18]. Aboody \& Lev argue that there is a time lag in reporting profitability of R\&D and thus suggest that it should be conservatively sustained at a certain level in accordance with prudence principle of accounting [1].

Expenses incurred by companies generally have three major; the first category is the operating expenditure which deals with expenses for the firm in the current period; second category consists of capital expenditure, which deals with expenses of the firm spanning multiple periods; and the third category consists of financial expenditure which are associated with debt capital of the firm. Critically analyzing these expenses, we note that financial expenses are paid for debt capital, while capital expenses are paid for long-term assets. Therefore, these two categories of expenditures should not form part of operating expenses and hence should not be 
included when computing a firm's operating income. However, capital expenditure may be depreciated or amortized over the period that the firm benefits from them [22]. Particular concern, therefore, is the inclusion of R\&D as an operating expense that can distort the estimation of a firm's operating income, and by extension, the net income.

The accounting standard requires R\&D expenditure to be totally expensed when incurred (GAAP), whereas, IAS 38 under the IASB framework, requires the research component expensed while the development component capitalized after satisfying the inclusion criteria [46]. This is because the accounting standards consider the ultimate $R \& D$ product to be uncertain and hence not easy to quantify. Therefore, R\&D as an internally generated asset largely misses out in the financial statements because of the insufficient description of an asset, which requires the identification, measurement, and control of these internally generated assets. This, therefore, leads to understating the firm's value [22].

Hall found the market value of listed firms and R\&D investments to have a positive relationship [37]. The study also found that stock prices positively follow the announcements of new R\&D investments. Related studies also found that markets react positively to R\&D investments announcements $[18,54]$. On the contrary, however, another study found that the market value of firms that heavily invest in R\&D is volatile over time [20]. This variability calls for the investigation of potential factors affecting the valuation of these firms' R\&D investment and consequently the criteria used to evaluate such investments in the capital markets.

According to IAS 38, research is the original planned search of knowledge done in order to acquire new scientific and technological thinking, while development is the use of research findings to plan for new or significantly improved products and services ahead of commercial implementation thereof. The System of National Accounts, 2008 (2008 SNA), defines research and development as a detailed statistical outline for macroeconomic policy development and research. The System of National Accounting (2008) recognizes R\&D as investment or an asset in the economy. The term 'Research and Development' is commonly used to describe the firm's activities undertaken to make new or to improve existing products and services. Among the activities included here are researches done by universities and laboratories and also product testing and refining before commercial or internal use (International Encyclopedia of Social Sciences, second edition, 2006). The Organization for Economic Co-operation and Development came up with most agreeable definition of R\&D which states that research and development (R\&D) include creative and systematic work done to increase the available knowledge and to come up with new usage of the existing knowledge [58]. Hence R\&D is carried out with an aim of generating new knowledge for economic benefit, solving challenges in the society or just creating knowledge for its own sake [58].

Research and development (R\&D) investments are among the intangible resources that constitute an increasingly important part of performance in companies in modern economies. Most firms have realized that intangible assets win them sustained competitive advantage than the tangible assets. The development of accounting standards to measure intangible assets value has taken long and is still controversial, making the disclosure of these unseen resources difficult [6]. Although firms are aware of the fact that all intangible assets are valuable and critical because they create value and decide future growth potential, it is evident that financial statements are not good at reflecting these assets [53]. Unlike the tangible assets, measuring intangible assets is complex because they are neither bought nor sold in an open market. Traditional accounting and management systems were designed during an era when tangible assets dominated the economies. However, this has changed significantly towards intangible asset investments, but the accounting systems have largely remained the same [53].

Firms investing heavily in R\&D need to recognize it as an investment an asset in the balance sheet because it will ultimately generate cash flows to the firm. This recognition is in line with asset definition under the accounting standards. Unfortunately, investment in R\&D is either expensed in total or given a subjective treatment as prescribed in the U.S. GAAP and IASB's IAS 38 respectively. Consequently, different analysts come up with different values for the same firms or comparative firms depending on how these firms account for R\&D expenditures or how the analysts adjust their valuation inputs and figures to suit their beliefs.

This paper aims at providing critical and analytical review of the previous studies touching on the accounting treatment on $\mathrm{R} \& \mathrm{D}$ investments in relation to firm valuation. It is majorly supposed to contribute to: firstly suggesting to accounting standard setters on the accounting treatment and reporting of intangible investment so as to be more responsive to firm valuation; secondly, the study findings will help firms to formulate more realistic policies with regard to reporting $\mathrm{R} \& \mathrm{D}$ expenditures as it directly affects firm performance and resource allocation; and thirdly, the study findings will help in theory building. The ongoing debate on this subject is aimed at developing a universally acceptable theory through empirical studies. The gaps found will lead to further studies which will eventually lead to convergence of reporting standards on R\&D expenditure.

This study paper is arranged into four sections. The first section looks at the study background; the second section deals with theoretical literature review of the accounting treatment of intangible assets, and focus more closely at theories of research and development (R\&D) investments; section three looks at the empirical review of intangibles and R\&D investments; and finally, section four discusses the study findings and summarizes the review.

\section{Theoretical Literature Review}

The theories discussed here looks at the most related conjectures put forward by authors to explain the accounting treatment of R\&D investment. Financial statements provide 
important information relied upon by, among others, investors to make investment decisions, and financial analysts, to provide figures to value companies. Thus, there is need for accurate preparation of financial statements, carefully taking into account both tangible and intangible assets of the company. This section, therefore, looks at some of the theoretical literature involved.

The market-based view (MBV) explains the external market factors and industry characteristics that determine the performance of a firm [30]. The research work looked at the Structure-Conduct-Performance (SCP) and focused on the five-force model. The theory analyses the unique sets of activities performed by a firm that set it apart from its rivals. The strategic advantage of a firm is determined by how it does similar activities differently from other rival firms. The performance of the firm to is determined by its structure and competitive strength in the relevant industry.

Entry barriers, distinct products, competitor volume and demand level are the factors affecting firm's behavior [2]. Other researchers who advanced the SCP framework found that organizations can have competitive advantage over others by engaging in activities that responds to the structure of their industry [14]. Firms achieve this by basing their performance against the Porter's five force model. These are; entry barriers, substitute threats, supplier bargaining power, buyer bargaining power and competitor rivalry [62]. Also according to study by Bessieux-Ollier et al., three most common basis of market power are: monopoly, entry barrier, and bargaining power [13]. Firms that have monopoly exhibit strong market position which makes them perform better [24]. High barriers to entry reduce competition leading to better performance.

However, Porter's five-force factors have limitation because it assumes both a perfect and static market structures, which are not easy to achieve. The five-force model is also complex in terms of industry interrelationships [29]. A contrary opinion argues that important factors that determine firm profitability are unique to the firm, and not the industry [28]. Competitive advantage that depends on firm capabilities and resources outweigh those based on products and market positioning [24]. They consider heterogeneous resources as main contributors to firm's competitiveness. These studies shifted the focus and suggested that from 1980s onwards, studies in strategic management would move from the structure of the industry, that is, market based structure (MBV) to the firm's internal structure involving resources and capabilities, also known as resource based structure (RBV) [24].

The Resource Based View (RBV) focuses on the internal resources of a firm as well as their strategic strength to achieve sustainable competitive advantages [35]. These will enable the firm to compete in the external business environment by offering better products and services and ensuring improved quality of the supply and value chain. According to this theory, competitive advantage will only be achieved if the firm practices resource heterogeneity and immobility.
The theory focuses on "difficult to imitate" characteristics of a firm in order to come up with high quality products and services as compared to other competitors [25]. The RBV scrutinises why firms thrive or flop in the market [24]. Resource Based Theory views an organization as comprising, human resource, physical resource and organizational resource [4]. Organizations consider resources of higher value, scarce, not easy to imitate and not easily substituted as those contributing to sustained higher performance and competitive advantage of a firm [8].

A highly performing and competitive resource fulfils the criteria of VRIN; that is, 1) Valuable (V): which means that it should provide strategic value to the firm by helping the firm to explore opportunities and reduce threats in the market place; 2) Rare (R): firm's resources should be unique and rare and difficult to find among competitors in order to be competitive; 3) Imperfect Imitability (I): it should not be easy to copy resources used by an organization to make it competitively feasible; 4) Non-Substitutability (N): this means that it must be difficult to substitute resources controlled by a firm to deny competitors the ability to achieve equally better performance.

According to Barney, a resource is valuable if it leads the firm to make comparatively higher sales, incur lower costs, and thus achieve higher margins [8]. Additionally, the author underscored the need for resources to enable a firm to come up with strategies that make it efficient and effective in its performance. Therefore, RBV gives managers of firms an understanding of the importance of competencies as the most valuable asset of a firm in achieving superior performance [38].

Despite the argument by most RBV researcher that knowledge is a generic resource of a firm, some researchers take knowledge to be a valuable resource because of its unique feature $[5,65]$. Others argue that, in this information age, knowledge; intellectual capital, competencies and such like attributes are important when it comes to firm's superior performance [61]. Another study pointed out that the more the knowledge asset is used by a firm, the higher the value it creates as compared to physical assets of a firm [70]. Amrit et al., further argue that technology, capital of the firm, market share and product sources are easily imitated compared to knowledge [5]. The study further suggests that knowledge theories views knowledge in five levels ordered as data, followed by information, knowledge, expertise and capabilities. On his part, Zack classifies knowledge into core, advanced, and innovative knowledge respectively [70]. According to him, core knowledge is the basic and required by firms for short-run market survival; advanced knowledge allows a firm to make peer comparison for short run competition; while innovative knowledge is required by firms for ranking against its competitors in the market. Therefore an innovative firm has the capabilities of introducing innovative products and services and thus positions itself as a market leader [70].

The basic role of financial reports is to reflect a firm's value for decision making. The following are the perspectives 
of value relevance according to sampled authors: 1) value relevance examines the association between accounting figures and firm's equity value [52]; 2) another study analyses value relevance in the following two ways: firstly, that stock prices are influenced by figures in the financial statements since they are used to capture a firm's intrinsic value; secondly, to be value relevant, the financial information should have the variables used as input in the valuation models or at least assists in predicting those variables [31]; 3) value relevance is the ability of financial statement information to record and report relevant information for firm value [12]. Therefore, standard setting bodies such as the IASB and the FASB should come up with high quality standards geared towards enhancing the quality of financial reports issued to stakeholders.

Accounting information is value relevant if it can predict a firm' market share price and returns [40, 48, 56]. Easton and Beaver did an empirical study on the association between security prices and fundamental accounting variables and found that such fundamental factors are associated with the market value of securities [11, 27]. Other studies looked at the adoption of International Financial Reporting Standards (IFRS) and its effect on a firm's earnings per share (EPS) and found that earnings announcements become value relevant if they influence investors to develop an appetite for shares [16, 19, 66]. This culminates in enhanced share price and share return.

From the FASB framework, R\&D costs are expensed when incurred, whereas its benefits are recorded later [63, 71]. This accounting treatment leads to distortion of the matching principle in accounting, and thus affects financial information value, specifically earnings and cash flows [46].

The analysis of a sizeable sample of US companies to disapprove the argument that exclusion of intangible asset investments negatively affects financial information value [23]. This study was supported by another study that used a sample of US companies taken between 1952 and 1994 [31]. However, from these studies, there was mixed reaction about the value of hi-tech versus low-tech firm. A similar study focusing on the periods between 1975 and 1999 also found mixed reaction about hi-tech versus low-tech firms [21].

Accounting Standards, IASB (2004) defines an intangible asset as "an identifiable nonmonetary asset without physical substance" [41]. Financial Accounting Standards Board (FASB, 2001) also defines an intangible asset as a "noncurrent, nonfinancial claim to future benefits that lacks a physical or financial term." The theoretical framework of accounting defines an asset as "a resource controlled by an entity as a result of past events from which future economic benefits are expected to flow into the entity."

The term "intangible" covers intangible assets, intangible investments, as well as intangible capital (or intellectual capital, knowledge capital or goodwill). Hence intangibles are listed into three main categories; in the first category, property rights and markets exist and include copyrights, trademarks and patents; in the second category, property rights and markets are weak and these include $R \& D$ in progress, reputation, management structure and business secrets; and finally, intangible category with neither proper legal right nor markets such as human resource, structural assets, relational asset etc. [14]. Hence the last category has more accounting issues in comparison to the second, and much more compared to the first category. However, classifications given by accounting standard setting bodies divides intangible assets into two; internally generated, which are difficult to measure and externally acquired intangibles whose markets exist and hence can be quantified in terms of price.

Intangibles investment cut across manufacturing and service firms in the U.S. and such companies spend trillion of dollars annually on intangibles [56]. Studies also show that the share price of intangibles-intensive firms moves together with large premium as compared with book value. This shows that investors value investment in intangibles [46].

A study on 'Market Valuation of Companies investing heavily in R\&D,' compares those supporting with those opposing the capitalization of R\&D costs [57]. Those supporting expensing of $R \& D$ expenditure argue that there is uncertainty in reliably estimating such costs [42]. They further argue that allowing managers to decide on the amount amortized could reduce the quality of reported earnings [28]. However, those supporting the idea of capitalizing R\&D costs argue that there is enough evidence attached to $R \& D$ investments in term of future income [44]. Another study shows positive relationship between accounting figures and stock prices when $R \& D$ is capitalized as a balance sheet item balance sheet and amortized in future income statements [17]. Also, there is evidence of higher earnings quality in terms of price/earnings association for firms capitalizing rather than those immediately expensing R\&D investment [50].

To include intangible assets in the balance sheet, it must meet the set recognition criteria in the standards. Because of restrictive conditions for inclusion set by the standards, internally generated intangibles end up left out of the financial statements [13]. The accounting framework emphasizes "control" as an imperative inclusion criterion when defining an asset. The framework states that for a firm to have control over an asset, it has to exclusively benefit from it while disallowing other firms from such benefits. However, on the flip side, it is not easy to control human resource even after benefiting from the firm in terms of training and experience [45]. A study on "partial excludability", justifies the argument that such intangible resource should not be capitalized due to the uncertainty of employee-employer contract as employees can easily switch employment from one firm to the next [45].

The accounting framework is also concerned about the reliability of measurement of the asset's value. However, because of the difficulty involved in measuring R\&D investment, which is an internally generated asset, the FASB framework recommends the immediate expensing of the cost, while the IASB framework recommends expensing the research costs, while capitalizing the development costs after satisfying the set recognition criteria of technical feasibility 
(IAS 38/SFAS 5). However, the FASB gives an exception to computer software firms by allowing the development cost of computer software to be capitalized after satisfying the conditions set for technological feasibility (SFAS 86).

Standard setting bodies have made efforts to development of sound standards in order to improve the quality of financial reporting. Thus, various accounting bodies and institutes have made contributions to these efforts because different stakeholders rely on financial reports for decision making. These bodies have made effort to come up with guidelines and models to improve the quality of financial reporting (AICPA, 1994; CICA, 1995; ICAEW, 2000; FASB, 2001). They have formulated various disclosure requirement for disclosing nonfinancial information and other specific disclosures on intangible assets [10, 58]. These efforts are discussed next.

The US, through the Institute of Certified Public Accountants (ICPA) constituted the Jenkins Committee of 1991. This committee noted that financial statement users required both historical and futuristic information on firm performance. They recommended the replacement of traditional financial reporting with one known as the Business Model which reports both financial and wealthcreating information of an enterprise with strategic plans. Additionally, AICPA together with the FASB steering committee submitted a report in 2001 on "Improving Business Reporting: Insights into Enhancing Voluntary Disclosure." The objective was to formulate a reporting framework that encourages coherent and voluntary disclosures of key success factors of a firm.

Another body, the Canadian Institute of Chartered Accountants (CICA) initiated "Performance Measures in the New Economy," (1994). They identified nonfinancial reporting as key to strategic planning and hence shareholder value. On the other hand, The Institute of Chartered Accountants in England and Wales (ICAEW), through Charles Leadbeater, studied "New Measures for the New Economy" and recommended an incremental approach for intangibles. That is, traditional financial reporting is maintained as key requirement for corporate reporting and supplemented by nonfinancial reporting aimed at helping investors interested in intangible valuation.

Subsequently, the Securities and Exchange Commission (SEC) in the US and the Canadian Securities Administrators (CSA) put forth a requirement for publicly listed companies to issue on the face of their annual report known as Management Discussion and Analysis (MD\&A). This is aimed at giving detailed narration and analysis on nonfinancial information. The European Commission also adopted these recommendations in their 'Business Review' (2005), and required directors to include such reports in order to enhance their reporting.

A reporting model known as Intangible Capital Statement was developed by the Danish Agency for Trade and Industry (DATI). This model combines narrations, graphics and figures for disclosing specific information on intangibles (DATI, 1998). The objectives of the model are two-fold; one is internal; for management decision making and the other is external; for reporting annual accounts. This model allows firms to give an account of their effort in developing knowledge resource.

Another specific model known as MERITUM project was developed by the European Union, in 2002. It set out the guidelines for management and reporting intangibles to improve intangible asset management and to encourage directors to voluntarily disclosure such assets. In Germany, the Federal Ministry of Economics and Labor developed an "Intellectual Capital Statement" reporting model in 2004. In 2005, the Japanese through Ministry of Economy, Trade and Industry (METI), developed a disclosure guideline for intangible assets for management. All these are geared towards improving the reporting of intangible investment of firms.

\section{Review of Empirical Studies}

Empirical studies highlighted here are organized as studies that have had impact on the knowledge area of accounting treatment of $R \& D$ expenditure on firm value. A majority of these studies have looked at the association between general and specific disclosure on intangibles. These studies have further paid attention on the effect of such disclosures on the following: 1) value relevance of financial information; 2) resource allocation of the firm; 3) growth of intangibles in the firm; and 4) market value of the firm. This section discusses the empirical evidence provided by different authors on the mentioned subheadings.

Voluntary disclosure serves as a way of compensating for the loss of financial statement value relevance. Managers disclose more information by way of press releases, give evidence of managers voluntarily disclosing such information through annual reports and conference calls [51]. A study of US cellular firms shows that nonfinancial information has more value than traditional financial information [3]. The findings of this study is supported by another study that used a sample of electronic companies in Taiwan to show that companies largely use nonfinancial information to supplement financial information for valuation purposes [47]. Additionally, another study supported the value relevance of financial information through their study of IT firms in Taiwan and found that combining both financial and nonfinancial information greatly adds value the explanatory power (given by $\mathrm{R}^{2}$ ) of equity valuation model [69].

However, there is a contrary opinion that tangible and intangible assets are inseparable when it comes to measuring productivity of a firm [9]. The authors in the cited study supported this observation by looking at the macroeconomic variables of education reforms, legal reforms, networking, among others as being stimuli to encourage knowledge transformation for improved firm productivity. According to their study, it is not economical to separate intangible from tangible assets and hence managers can only disclose nonfinancial information.

A study conducted in Australian Health-Care Industry with regards to R\&D's value relevance compared periods before 
and after the introduction of IAS 38 and found R\&D investment to be value-relevant $[49,55]$. The finding is attributed to capitalizing the development component of R\&D expenditure as opposed to totally expensing it as before. This is in accordance to the requirement of the accounting standard IAS 38.

In summary, therefore, majority of the studies point to voluntary disclosure of $R \& D$ and other intangibles as possible solution to the value relevance inadequacy of financial information, and that incorporating such information into models of equity valuation compensates for the 'missing input' required by analysts in valuing firms.

Managers tend to voluntarily disclose more information about on intangible investments of their firms to avoid undesirable outcomes caused by nondisclosures of such information. A study on 312 firms listed in the US stock exchange found that most managers $(44 \%$ as opposed to $17.4 \%$ ) were in agreement that voluntary disclosure improved liquidity of their stock [34]. Another study empirically validated this finding by using AIMR rankings to conclude that disclosure improves liquidity of stock while at the same time reducing variations in analysts' forecasts [39].

On the cost of capital, Graham et al., found that $39.3 \%$ as opposed to $22 \%$ of managers contend that voluntary disclosure reduces the cost of capital [34]. This statement validates another study which used self-constructed disclosure index of US companies and found that firms that disclosed nonfinancial information in their annual reports experienced lower cost of capital [15]. A study of the EU companies' annual reports on voluntary disclosure of intangible assets found strong empirical evidence that disclosure of futuristic information is tied to lower cost of capital [43]. A related study of EU companies found that enhanced intangibles disclosure has a negative relationship with information asymmetry as well as cost of both equity and debt capital [59].

Dinh et al., posed a study question: "can capitalization of R\&D improve investment efficiency?" They based their study on US GAAP by comparing investment in high-tech firms capitalizing R\&D with those that don't. They found that software firms which are allowed to capitalize their R\&D costs have improved resource allocation compared to those that don't capitalize [25].

Therefore, the analysis of these studies concludes that additional public disclosure on $\mathrm{R} \& \mathrm{D}$ as well as other intangibles reduces information asymmetry and hence the adverse selection in the capital market, resulting into greater liquidity and lower cost of capital. Overall, this may enhance market efficiency improve resource allocation efficiency in the capital market.

Empirical evidence show that enhanced disclosure of research and development investments and other intangible assets generated by firms can result in growth of intangible investments, consequently creating value to the firm [29]. A study on Canadian companies' disclosure practice and the level of growth in research and development in firms [31] found their relationship to be positive. Similarly, Gelb showed that companies would rather put more weight on voluntary disclosure than traditional accounting reporting so as to enhance R\&D growth [32].

A study of the annual reports of EU companies found a positive relationship between intangible assets investment and intangibles assets disclosure [67]. Similarly, Zeghal et al., looked at a sample of Canadian companies and found a significant positive movement between $R \& D$ disclosures and R\&D investment levels [72]. Additionally, other studies looked at the magnitude of intangible investments done by US companies in the high-tech sectors. They found that the higher the level of such investment, the more the frequency of disclosing such information [2, 64].

From these studies, it can be concluded that management voluntary disclosure of intangible assets can be viewed as an efficient communication channel to stakeholders who require comprehensive information on R\&D and other internally generated intangibles for their decision making. As observed in the analyzed studies, firms can use statutory reports, press statements, conferences, internet among other means to communicate nonfinancial information.

A number of studies also show that R\&D investments and other internally generated intangibles disclosure influence the firm's market value. In another study, the average stock price in the US pharmaceutical industry rose to $1.13 \%$ up from $0.51 \%$ in the absence of such information [46]. Further, in addition to both qualitative (nonfinancial) and quantitative information, when the board announced the approval of drugs under research, the average reaction rose to $2.01 \%$.

A survey conducted on finance professionals in Hong Kong found $88 \%$ agreeing that enhanced intangibles disclosure will positively influence a company's stock price [60]. Validating this finding is a study that looked at how disclosure of intangible assets is related to a firm's market capitalization [2]. This study found a significant positive relationship between voluntary disclosure and a firm's market capitalization. A study of internationally quoted telecommunication companies that largely use websites besides the annual reports to disclose intangibles found a significant positive movement between intangibles disclosure and market capitalization [33].

A theoretical review of mean-variance analysis on investment decisions of firms at different stages of business development that focused on Australian accounting information found a positive association between intangibles investment and return on equity [26]. This study finding validates the theory put forward by another study which suggests that for internally generated intangible to be considered an asset, its investment should be clearly irreversible [73].

Therefore, it can be concluded, from the analysis of different authors under this subheading that, when information about internally generated assets is publicly disclosed, such information can supplement the traditional financial reporting. Consequently, firms can be rewarded by the capital markets for disclosure of such nonfinancial information. 


\section{Study Gaps}

analyzed studies which require further researches in order to

The following table summarizes the gaps identified in the improve the theory in this study area.

Table 1. Study gaps.

\begin{tabular}{|c|c|c|c|}
\hline Author/Article & $\begin{array}{l}\text { Research Methodology } \\
\text { Applied }\end{array}$ & Key Findings & Limitations/Gaps \\
\hline $\begin{array}{l}\text { Longee \& Marquardt (2004) } \\
\text { Earnings Information and } \\
\text { Strategic Disclosure: An } \\
\text { Empirical Examination of } \\
\text { "Pro Forma" Earnings }\end{array}$ & $\begin{array}{l}\text { They used a sample of press } \\
\text { releases from } 249 \text { U.S. } \\
\text { companies between } 1997 \text { and } \\
1999\end{array}$ & $\begin{array}{l}\text { Firms with minimal accounting earnings } \\
\text { are likely to disclose their pro forma } \\
\text { earnings. Also in the absence of strategic } \\
\text { information, firms disclose their pro forma } \\
\text { earnings. }\end{array}$ & $\begin{array}{l}\text { They could not clearly determine whether } \\
\text { investors overreacted to pro forma earnings } \\
\text { information at the expense of market efficiency } \\
\text { or mispricing. }\end{array}$ \\
\hline $\begin{array}{l}\text { Basu \& Waymire (2008) } \\
\text { Has the Importance of } \\
\text { Intangibles Really Grown? } \\
\text { And If So, Why? }\end{array}$ & $\begin{array}{l}\text { They sampled international } \\
\text { firms for their study. }\end{array}$ & $\begin{array}{l}\text { They found intangibles to be synergistic, } \\
\text { cumulative, and mostly inseparable from } \\
\text { tangible assets and so it's wasteful to try to } \\
\text { estimate such figures. }\end{array}$ & $\begin{array}{l}\text { There is need to examine a broad set of } \\
\text { benchmarks to ascertain whether accounting for } \\
\text { intangibles is important. }\end{array}$ \\
\hline $\begin{array}{l}\text { Graham, Harvey, \&Rajgopal } \\
\text { (2005) To what extent does } \\
\text { disclosure improve liquidity } \\
\text { of stocks? }\end{array}$ & $\begin{array}{l}\text { They sampled about } 400 \\
\text { executives of listed US } \\
\text { companies. }\end{array}$ & $\begin{array}{l}\text { They found that managers preferred } \\
\text { economic activities that could have } \\
\text { undesirable long-term results to practicing } \\
\text { GAAP accounting to manage earnings. }\end{array}$ & $\begin{array}{l}\text { Contrary to the finding, } 78 \% \text { of the sample } \\
\text { admits giving up long-term benefits for smooth } \\
\text { earnings. This requires further investigation. }\end{array}$ \\
\hline $\begin{array}{l}\text { Chuan, Dinh, \&Sidhu (2019): } \\
\text { Can Capitalization of R\&D } \\
\text { Improve Investment } \\
\text { Efficiency? }\end{array}$ & $\begin{array}{l}\text { They investigated hi-tech } \\
\text { firms that do not capitalize } \\
\text { R\&D costs in comparison to } \\
\text { software firms. }\end{array}$ & $\begin{array}{l}\text { Hi-tech firms that do not capitalize R\&D } \\
\text { costs experience under-investment as } \\
\text { compared to software development firms. }\end{array}$ & $\begin{array}{l}\text { They found no evidence of over-investment at } \\
\text { the existence of financial flexibility. This } \\
\text { requires further investigation. }\end{array}$ \\
\hline $\begin{array}{l}\text { Guthrie \& Petty, Ricceri } \\
\text { (2008) The voluntary } \\
\text { reporting of intellectual } \\
\text { capital: Comparing evidence } \\
\text { from Hong Kong and } \\
\text { Australia }\end{array}$ & $\begin{array}{l}\text { They sampled } 70 \text { listed } \\
\text { Australian companies in } 1998 \\
\text { and } 100 \text { in Hong Kong. }\end{array}$ & $\begin{array}{l}\text { They found voluntary disclosure levels of } \\
\text { Intellectual Capital (IC) to be low. They } \\
\text { also found disclosure levels to be } \\
\text { positively related to firm size. The } \\
\text { information was largely qualitative rather } \\
\text { than quantitative. }\end{array}$ & $\begin{array}{l}\text { External validity may be questionable as a result } \\
\text { of the relatively small sample size. Also } \\
\text { managers were not observed in the survey, so } \\
\text { management intent is simply inferred. }\end{array}$ \\
\hline
\end{tabular}

\section{Summary, Conclusion and Recommendations}

This study has critically analyzed the studies by various researchers in the area surrounding the consequences of accounting treatment on $R \& D$ investment in firms with significant R\&D expenditures culminating to an internally generated intangible. There is significant statistical evidence that intangible assets are becoming the key creator of value for a sizeable number of firms in the modern economy. However, this kind of investment has been given inadequate accounting treatment as have been discussed in the earlier sections. This is because, within the accounting framework, there is a challenge in the identification, measurement and control of such intangible assets.

In summary, the lack of adequate accounting treatment on R\&D investments has raised concerns with many researchers investigating the impact of current accounting treatment on R\&D investment-intensive companies under the headings; the value relevance of financial reports; allocation of resources in the capital market; growth of intangibles investments; and the firm's market value.

Studies conducted to probe how accounting treatment of nonfinancial information affect the value of financial reporting has resulted into varied findings, with different authors giving opposing findings on the same. The differing conclusions arrived at by the authors are as a result of failing to capture information related to intangible assets in financial statements of firms, and hence missing it out as an input in the valuation models of companies. On the other hand, incorporating voluntarily disclosed intangible assets in the company's financial statements has been viewed as taking care of the loss of value on financial information. Profitability is also found to increase with increase in R\&D investment as evidenced in studies by studies [7, 68]. Studies on mean-variance analysis of firms by authors found a positive relationship between investment in intangible assets and equity returns [26].

Studies done on the misallocation of resources in the capital market has identified lack of adequate accounting treatment of R\&D investments as cause of misallocation of resources for R\&D-intensive firms. However, latest studies have indicated that enhanced disclosure of the existence of intangible investments contributes to improved efficiency in market operations at large and reduce the cost of capital while giving way to better resource allocation in the capital market.

Studies on growth of R\&D, an internally generated intangible for companies, has shown that accounting treatment of R\&D investment did not substantially hinder its growth. Supporting this finding is the fact that companies communicate information of their investments in intangibles annually by way of financial reports, conference calls, websites, and press releases among other channels of disclosure. Another study validated this finding using R\&D data of sampled UK and other International companies within the period of 2001 to 2007 . Some studies show that increased level of investment in $\mathrm{R} \& \mathrm{D}$ can lead to enhanced disclosure of internally generated intangibles [72]. 
Studies on inadequate accountability of R\&D investment as compared to the market value show that there is systematic misevaluation of companies that invest heavily in R\&D. Some studies indicate undervaluation while others indicate overvaluation of such companies. However, these studies show that the misevaluation of companies can be mitigated by providing adequate disclosure on $R \& D$ and other internally generated intangibles. Capitalizing R\&D costs has been found to mitigate the under-investment in high-tech firms as evidenced in computer software firms especially in the U.S., which allows such companies to capitalize these cost, as opposed to their counterparts in other industries [25]. However, there is evidence that firm managers may take advantage of capitalizing such costs to manage earnings [25, 36].

From the discussions summarized above, it is evident that disclosure of intangibles can greatly improve the financial information provided to users of financial reports. This will as well reward firms in the capital markets. Therefore, the management of firms should provide adequate information about their intangibles investments, and specifically, the internally generated intangibles such as R\&D more prominently. The accounting standards setters should pay attention to accounting for intangibles and come up with universal guidelines of reporting such internally generated intangibles.

Most researchers agree that R\&D investment significantly influence the value of a firm and therefore needs to be capitalized in the financial statements in order to reflect this value. This would enhance efficiency and improve accuracy in valuing and analyzing firms. Analysts will therefore eliminate the problem of undervaluing these firms, and this, will in turn lead to efficiency in allocating resources to these firms by investors in the capital markets.

The critical analysis of literature and empirical studies still leaves room for discourse and study. This is because there is no conclusive theory about the universal accounting standards on R\&D investment applied across the financial statements of firms, leading to non-uniformity of financial reporting and hence misevaluation of firms. Therefore, more studies should be carried out to find the best measurement and reporting models for R\&D costs, and by extension, intangible assets that will eliminate subjective assignment of costs. Also studies should be carried out on the best methods of classifying companies with various levels or intensity of $\mathrm{R} \& \mathrm{D}$ investments and other intangible assets so as to find the best measurement and reporting models for each category.

\section{References}

[1] Aboody, D. \& B. Lev (2000). Information Asymmetry, R\&D, and insider gains Journal of Finance, 55 (6), 2747-2766.

[2] Abdolmohammadi, M. J. (2005). Intellectual capital disclosure and market capitalization. Journal of Intellectual Capital, 6 (3), 397-416.
[3] Amir, E., \& Lev, B. (1996). Value-relevance of nonfinancial information: The wireless communications industry. Journal of Accounting and Economics, 22, 3-30.

[4] Amit, Raphael \& Shoemaker, Paul. (1993). Strategic Assets and Organizational Rent. Strategic Management Journal Strategic Management J. 14. 33-46. 10.1002/smj.4250140105.

[5] Amrit Tiwana. (2000). The knowledge management toolkit: practical techniques for building a knowledge management system. Prentice Hall PTR, USA.

[6] Austin, Lloyd. (2007). Accounting for intangible assets. University of Auckland, Business Review, Vol. 9, No. 1.

[7] Ayaydın, H, Karaaslan, İ. (2014). The Effect of Research And Development Investment On Firms' Financial Performance: Evidence From Manufacturing Firms In Turkey. Bilgi Ekonomisi ve Yönetimi Dergisi, 9 (1), 23-39.

[8] Barney, J. (1991) Firm Resources and Sustained Competitive Advantage. Journal of Management, 17, 99-120. http://dx.doi.org/10.1177/014920639101700108.

[9] Basu, S., \& Waymire, G. (2008). Has The Importance of Intangibles Really Grown? And if so, why? Journal: Accounting and business research, 38: 3, pp 171-190.

[10] Beattie, V., McInnes, B., \& Fearnley, S. (2004). A Methodology for Analysing and Evaluating Narratives in Annual Reports: A comprehensive descriptive profile and metrics for disclosure quality attributes. Accounting Forum, $28,205-236$.

[11] Beaver W. H. (2002). Perspectives on Recent Capital Market Research. Accounting Journal, 77: 453-74.

[12] Beisland, Leif. (2009). A Review of the Value Relevance Literature. The Open Business Journal - Open Bus J. 2. 10.2174/1874915100902010007.

[13] Bessieux-Ollier, C., Lacroix, M., \& Walliser, E. (2006). Le capital humain: Approche comptable versus approche managériale. Revue internationale sur le travail et la société, 4 (2), 25-57.

[14] Blair, M. M., \& Wallman, S. M. H. (2000). Unseen wealth: Report of the Brookings task force on understanding intangibles sources of value. Washington, DC: The Brookings Institution Press.

[15] Botosan, C. A. (1997). Disclosure level and the cost of equity capital. The Accounting Review, 72 (3), 323-349.

[16] Chalmers, Keryn., Clinc, Geg., Godfrey, \& Jayne M, (2011). Change in Value Relevance of Accounting Information upon IFRS Adoption: Evidence from Australia. Australian Journal of Management, 36 (2): 151-171.

[17] Chambers, D., Jennings, R., \& Thompson, R. (2002). Excess returns to R\&D intensive firms. Review of Accounting Studies, 7, 133-158.

[18] Chan, Louis K. C., Jason Karceski, \& Josef Lakonishok, (2000). New paradigm or same old hype in equity investing? Financial Analysts Journal 56, 2336.

[19] Clarkson, Peter and Hanna, J. Douglas and Richardson, Gordon D. and Thompson, Rex W., The Impact of IFRS Adoption on the Value Relevance of Book Value and Earnings (April 14, 2011). Journal of Contemporary Accounting and Economics. 
[20] Cockburn, Iain \& Griliches, Zvi, 1988. "Industry Effects and Appropriability Measures in the Stock Market's Valuation of R\&D and Patents," American Economic Review, American Economic Association, vol. 78 (2), pages 419-423.

[21] Core, J. E., Guay, W. R., \& Van Buskirk, A. (2003). Market Valuations in the New Economy: An Investigation of What Has Changed. Journal of Accounting and Economics, 34 (1-3), 43-67. http://dx.doi.org/10.1016/S0165-4101(02)00087-3.

[22] Damodaran, A., (2004). Investment Valuation. John Wiley \& Sons, Inc., Hoboken, New Jersey.

[23] Daniel W. Collins, Edward L. Maydew, Ira S. Weiss, Changes in the value-relevance of earnings and book values over the past forty years, Journal of Accounting and Economics, Volume 24, Issue 1, 1997, ISSN 0165-4101, https://doi.org/10.1016/S0165-4101(97)00015-3.

[24] Dickson, P. R. (1996). The Static and Dynamic Mechanics of Competition: A Comment on Hunt and Morgan's Comparative Advantage Theory. Journal of Marketing, 60 (4), 102-106. https://doi.org/10.1177/002224299606000409.

[25] Dinh, Tami; Sidhu K., Baljit \& Yu, Chuan (2019) Accounting for Intangibles: Can Capitalization of R\&D Improve Investment Efficiency? ABACUS - A Journal of Accounting, Finance and Business Studies, 55 (1). 92-127.

[26] Dotcherly, P., Chan, H., \& Easton, S. (2013). Australian evidence on the implementation of the size and value premia. Accounting \& Finance, 53 (2), 367-391. https://doi.org/10.1111/j.1467-629X.2011.00464.x.

[27] Easton, P. (1985). Accounting Earnings and Security Valuation: Empirical Evidence of the Fundamental Links. Journal of Accounting Research, 23, 54-77. doi: $10.2307 / 2490689$.

[28] Ely, Kirsten and Waymire, Gregory B., Intangible Assets and Equity Valuation in the Pre-Sec Era (April 1999). Available at SSRN: https://ssrn.com/abstract $=158669$ or http://dx.doi.org/10.2139/ssrn.158669.

[29] Entwistle, G. M. (1999). Exploring the R\&D disclosure environment. Accounting Horizons, 13 (4), 353-385.

[30] Ferguson P. R. (1988) The Structure-Conduct-Performance Paradigm. In: Industrial Economics: Issues and Perspectives. Palgrave, London. https://doi.org/10.1007/978-1-349-19211-3_2.

[31] Francis, J., \& Schipper, K. (1999). Have Financial Statements Lost Their Relevance? Journal of Accounting Research, 37 (2), 319-352. doi: 10.2307/2491412.

[32] Gelb, D. S. (2002). Intangible assets and firms' disclosures: An empirical investigation. Journal of Business Finance \& Accounting, 29 (3\&4), 457-476.

[33] Gerpott, T. J., Thomas, S. E., \& Hoffmann, A. P. (2008). Intangible asset disclosure in the telecommunications industry. Journal of Intellectual Capital, 9 (1), 37-61.

[34] Graham, J., Harvey, C., \& Rajgopal, S. (2005). The economic implications of corporate financial reporting. Journal of Accounting and Economics, 40, 3-73.

[35] Grant, Robert M., (1991) "The resource-based theory of competitive advantage: implications for strategy formulation" from California Management Review 33 (3) pp. 114-135, Berkeley, Calif.: University of California ${ }^{\circ}$.
[36] Guidara, R, Boujelbene, Y. (2015). R\&D Expenditures and Earnings Targets: Evidence from France. Journal of Economics Finance and Accounting 2 (2), 0-0. https://dergipark.org.tr/en/pub/jefa/issue/32427/360575.

[37] Hall, B. H. (2002). The financing of research and development. Oxford Review of Economic Policy, 18 (1), 35-51.

[38] Hamel \& Prahalad (1989). Strategic Intent. Harvard Business Review, May - June 1989.

[39] Healy, P. M., Hutton, A. P., \& Palepu, K. G. (1999). Stock performance and intermediation changes surrounding sustained increases in disclosure. Contemporary Accounting Research, 16 (3), 485-520.

[40] Holthausen, R. and Watts, R. (2001). The Relevance of the Value-Relevance Literature for Accounting Standard Setting. Journal of Accounting and Economics, 31, 3-76. http://dx.doi.org/10.1016/S0165-4101(01)00029-5.

[41] International Financial Reporting Standards handbook www.ifrs.org.

[42] Kothari, S. P., Laguerre, T. E., \& Leone, A. J. (2002). Capitalization versus expensing: Evidence on the uncertainty of future earnings from capital expenditures versus R\&D outlays. Review of Accounting Studies, 7, 355-382.

[43] Kristandl, G., \& Bontis, N. (2007). The impact of voluntary disclosure on cost of equity capital estimates in a temporal setting. Journal of Intellectual Capital, 8 (4), 577-594.

[44] Lev, Baruch. \& T. Sougiannis (1996). The capitalization, amortization, and value relevance of R\&D. Journal of Accounting \& Economics, 21 (1), 107-138.

[45] Lev, B. (2001). Intangibles: Management, measurement and reporting. Washington, DC: Brookings Institution Press.

[46] Lev, B. (2003). Remarks on the measurement, valuation, and reporting of intangible assets. FRBNY Economic Policy Review, (September), 17-22.

[47] Liang, C. J, \& Yao, M. L. (2005). The value-relevance of financial and nonfinancial information-Evidence from Taiwan's information electronics industry. Review of Quantitative Finance and Accounting, 24, 135-175.

[48] Liu, Jing and Ohlson, James A., The Feltham-Ohlson (1995) Model: Empirical Implications. Available at SSRN: https://ssrn.com/abstract $=180452$ http://dx.doi.org/10.2139/ssrn.180452.

[49] Lorena Mitrione, George Tanewski, \& Jacqueline Birt (2013). The relevance to firm valuation of research and development expenditure in the Australian health care industry. Australian Journal of Management (Sage Publications Inc.).

[50] Loudder, M. L. and B. K. Behn. (1995). "Alternative Income Determination Rules and Earnings Usefulness: The Case of R\&D Costs." Contemporary Accounting Research 12, 185-205.

[51] Lougee, B., \& Marquardt, C. (2004). Earnings in formativeness and strategic disclosure: An empirical examination of "Pro Forma" earnings. The Accounting Review, 79 (3), 769-795.

[52] Mary E. Barth, William H. Beave and Wayne R. Landsman (2001). The relevance of the value relevance literature for financial accounting standard setting. Journal of Accounting and Economics, vol. 31, issue 1-3, 77-104. 
[53] Mehta, Archana Dinesh and Madhani, Pankaj M., Intangible Assets - An Introduction. The Accounting World, Vol. 8, No. 9, pp 11-19, 2008, Available at SSRN: https://ssrn.com/abstract=1504544.

[54] McConnell, J. J., \& Muscarella, C. J. (1985). Corporate capital expenditure decisions and the market value of the firm. Journal of Financial Economics, 14 (3), 399-422. https://doi.org/10.1016/0304-405X(85)90006-6.

[55] Mitrione, L., Tanewski, G., \& Birt, J. (2014). The relevance to firm valuation of research and development expenditure in the Australian health-care industry. Australian Journal of Management, $\quad 39 \quad$ (3), 425-452. https://doi.org/10.1177/0312896213496256.

[56] Nakamura, I. L. (2008). Intangible Assets and National Income Accounting, Federal Reserve Bank of Philadelphia Review of Income and Wealth Series 56, Special Issue 1, June2010.

[57] Nissim and Thomas (2002). Equity Valuation Using Multiples. Journal of Accounting Research, Vol. 40 No. 1 March, 2002.

[58] OECD (2015). The Measurement of Scientific and Technological Activities: Proposed Standard Practice for Surveys on Research and Experimental Development.

[59] Orens, R., Aerts, W., \& Lybaert, N. (2009). Intellectual capital disclosure cost of finance and firm value. Management Decision, 47 (10), 1536-1554.

[60] Petty, R., Ricceri, F., \& Guthrie, J. (2008). Intellectual capital: A user's perspective. Management Research News, 31 (6), 434-447.

[61] Prahalad, C. K. and Hamel, Gary, The Core Competence of the Corporation (1990). University of Illinois at UrbanaChampaign's Academy for Entrepreneurial Leadership Historical Research Reference in Entrepreneurship, Available at SSRN: https://ssrn.com/abstract=1505251.

[62] Rumelt, R. (1991). How Much Does Industry Matter? Strategic Management Journal, 12 (3), 167-185. from http://www.jstor.org/stable/2486591.
[63] Siegel, Philip H. The Measurement and Recognition of Intangible Assets (December 5, 2007). Journal of Public Affairs, Vol. 1, No. 1, 2006, Available at SSRN: https://ssrn.com/abstract=913973.

[64] Sonnier, B. M. (2008). Intellectual capital disclosure: Hightech versus traditional sector companies. Journal of Intellectual Capital, 9 (4), 705-722.

[65] Teece, D. J. \& Pisano, G. \& Shuen, Amy. (2003). Dynamic capabilities and strategic management. 10.1142/9789812796929 0003 .

[66] Tsalavoutas, Ioannis \& Tsoligkas, Fanis \& Evans, Lisa. (2020). Compliance with IFRS mandatory disclosure requirements: $a$ structured literature review.

[67] Vergauwen, P., Bollen, L., \& Oirbans, E. (2007). Intellectual capital disclosure and intangible value drivers: An empirical study. Management Decision, 45 (7), 1163-1180.

[68] Warusa with Arana, M. (2015), Research and development, profits, and firm value: A structural estimation. Quantitative Economics, 6: 531-565. https://doi.org/10.3982/QE282.

[69] Yu, H. C. Wang, W. Y., \& Chang, C. (2009). The pricing of intellectual capital in the IT industry. Working paper, www.ssrn.com.

[70] Zack, M. H. (1999). Developing a Knowledge Strategy. California Management Review, 41 (3), 125-145. https://doi.org/10.2307/41166000.

[71] Zarowin, P. (1999). Discussion of Intangible Assets and stock Prices in the Pre-SEC era. Journal of Accounting Research Vol. 37 pp. $45-51$ https://doi.org/10.2307/2491344.

[72] Zéghal, D., Mouelhi, R., \& Louati, H. (2007). An analysis of the determinants of research \& development voluntary disclosure by Canadian firms. The Irish Accounting Review, 14 (2), 61-89.

[73] Zhang, Lu, The Value Premium (November 13, 2002). Simon School of Business Working Paper No. FR 02-19. 